\title{
Frozen-thawed Abdominal Flap Remnant as an education material for a Medium Group Surgical Skills Education Workshop
}

\author{
Sin Young Song, Min Kyu Kang, Eun Key Kim \\ Department of Plastic Surgery, Asan Medical Center, University of UIsan College of Medicine, Seoul, Korea
}

\begin{abstract}
Purpose: Residents' duty-hour regulations and the evolution of minimally invasive surgical techniques require more effective and efficient surgical skill teaching models. We used frozen-thawed human tissue remnants harvested during abdominoplasty or abdominal tissue-based breast reconstruction to allow for a medium-sized group workshop program, simulating a realistic surgical environment and visual/haptic feedback.

Methods: Full-thickness abdominal tissue (skin and subcutaneous fat) were donated from patients who underwent autologous breast reconstruction and gave consent to use their tissue for comprehensive research and medical educational purposes. Anonymized tissue was frozen-preserved and then thawed the day of the surgical skills workshop. A total of 53 residents completed 50-minute hands-on training in 3-to-5 person modules in four sessions of the workshop program.

Results: Thawed tissue regained almost normal texture and consistency. Structural integrity was also histologically confirmed. All participants were generally satisfied with the program, especially regarding the suture material provided. Conclusion: Frozen-thawed tissue remnants from abdominoplasty or autologous breast reconstruction could be preserved and used as a suture education material in medium-group workshops for surgery residents or medical students given anonymity and with proper consent guaranteed. This approach provided an excellent model maintaining relatively real anatomic structure and consistency with minimal cost.

[Ann Surg Treat Res 2019;96(2):53-57]
\end{abstract}

Key Words: Education, Teaching, Training support, Sutures, Residency

\section{INTRODUCTION}

With developments in the field of less-invasive procedures such as endoscopy, laparoscopy and robotic surgery, the importance of achieving basic surgical skills remains one of the most important goals during surgical residency. Qualified residency education is even more important as fewer opportunities are given due to the abovementioned surgical development and duty-hour regulations $[1,2]$. Workhour limitations, financial constraints, and ethical concerns have forced educators to explore new options for increasing the efficiency of training and teaching outside of the operating room [3].

Open suturing in accurate anatomic tissue layers and knot-tying with adequate tension are fundamental skills to minimize surgical complications and scarring [4]. Various education curricula and assessment tools have been developed and validated utilizing artificial suture pads and animal (mainly porcine) integument models [5-8]. Nevertheless, these materials are often too tough or too weak to mimic soft but elastic human
Received July 4, 2018, Revised September 3, 2018,

Accepted October 5, 2018

\section{Corresponding Author: Eun Key Kim}

Department of Plastic Surgery, Asan Medical Center, University of Ulsan College of Medicine, 88 Olympic-ro 43-gil, Songpa-gu, Seoul 05505, Korea Tel: +82-2-3010-3600, Fax: +82-2-476-7471

E-mail: nicekek@korea.com

ORCID code: https://orcid.org/0000-0002-3986-6886
Copyright (C) 2019, the Korean Surgical Society

(c) Annals of Surgical Treatment and Research is an Open Access Journal. All articles are distributed under the terms of the Creative Commons Attribution NonCommercial License (http://creativecommons.org/licenses/by-nc/4.0/) which permits unrestricted non-commercial use, distribution, and reproduction in any medium, provided the original work is properly cited. 
skin, and they differ in terms of composition of anatomic tissue layers, including epidermis, dermis, subcutaneous fat, and superficial fascia.

Abdominoplasty is a body-contouring surgery in which substantial amounts of normal abdominal skin and subcutaneous fat are excised and discarded from the lower abdomen [9]. Autologous breast reconstruction using abdominal tissue transfers almost identical to tissue of abdominoplasty, in order to reconstruct the breast after mastectomy, involves about one-third of the (most distal) tissue that cannot be used as part of the flap because of inherent perfusion problems [10]. These tissues are usually incinerated because they are not clinically or experimentally significant (Fig. 1).

We have been utilizing this tissue to teach medical student suturing and injection techniques immediately after surgery after gaining consent from the patients to use their tissue for comprehensive research and medical educational purposes. However, this curriculum should be continued year round
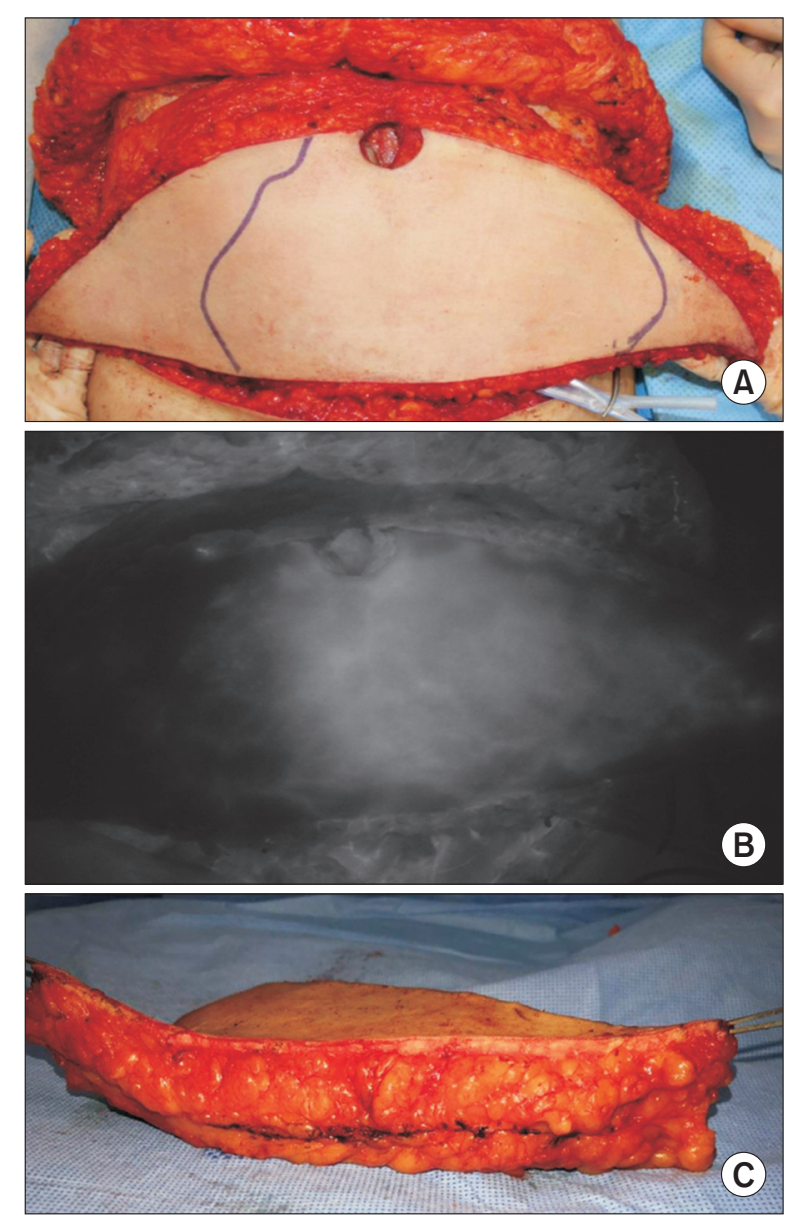

Fig. 1. (A) Abdominal flap (about $42 \mathrm{~cm} \times 14 \mathrm{~cm}$ ) was harvested from the patient's lower abdomen. (B) Fluorescence image demarcated the distal nonperfused part that should be discarded. (C) Excised distal part before freezing. Scarpa's fascia was marked with ink for photographic identification. for only a small number at one time. Work-hour regulations forces hospital staff to seek out efficient and effective training/ education curricula for residents from all surgery departments [1-3]. We recently held four sessions of a surgical skills workshop for a total of 53 residents from various surgery departments (13 to 14 in one session), and suturing was taught using frozenthawed abdominal tissue. We present our experience with a focus on tissue handling and ethical issues.

\section{METHODS}

The workshop included open suturing, airway management, central line insertion, and intraosseous injection, chest tube placement, and acute management of spinal cord injury and pelvic bone fractures. Two instructors participated in each 50-minute hands-on session teaching 3 to 5 residents. Suturing was taught by 2 board-certified plastic surgeons.

Abdominal tissue was obtained from patients who underwent autologous breast reconstruction and all gave consent to use their tissue for comprehensive research and medical educational purposes. Our Institutional Review Board granted exempt status for this protocol given that we obtained proper consent forms and removed all personal identification information (approval number: 2017-1249). After the surgery, abdominal tissue remnants were anonymized: all personal identifiers were removed because reidentification would not be necessary in any situation. Randomly-labeled tissues were rapidly frozen and maintained at minus $30^{\circ} \mathrm{C}$ for a few months, then slowly thawed on the night prior to use. The required number of tissues were stored at $4^{\circ} \mathrm{C}$ for about 12 hours, then maintained at room temperature for the final 4-5 hours. Thawed tissue returned to the status of fresh skin and subcutaneous fat including Scarpa's fascia. Tissue was then tacked on a plywood board and used for hands-on suture education and training, focusing on placing sutures at accurate anatomic layers and knot-tying with adequate tension (Fig. 2). Tissue samples were then transferred to pathology waste storage immediately after the workshop program and were disposed of by incineration along with other surgery/pathology specimens in accordance with our institution's regulations.

\section{RESULTS}

Tissue samples were stored frozen for 0.5 to 6 months prior to being thawed. A typical tissue specimen was a triangle-shaped full-thickness section of abdominal skin and subcutaneous fat with an average size of $10 \mathrm{~cm} \times 10 \mathrm{~cm}$ with varying thicknesses. Tissue samples regained normal texture and consistency after thawing. Microscopic evaluation confirmed almost normal histologic structure of the specimens (Fig. 3).

The teaching program covered tension-releasing deep tissue 

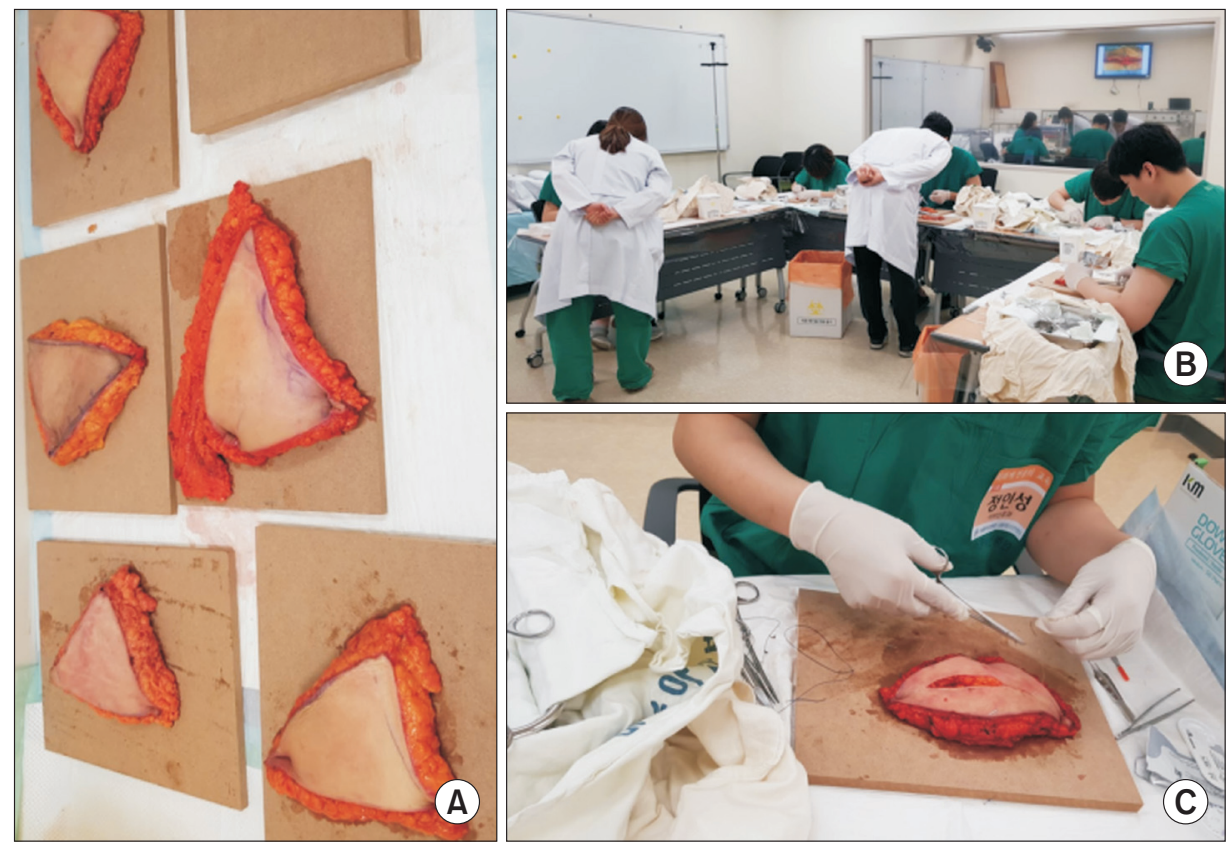

Fig. 2. (A) Five frozen-thawed human derivatives were tacked onto the plywood board for a module. (B) Two plastic surgeons participated in 50-minute handson modules. Each workshop program consisted of three such modules, teaching 13 to 14 residents in one day. A total of 53 residents completed training in 4 workshop days. (C) Suture education was performed with virtually real visual and haptic feedback.

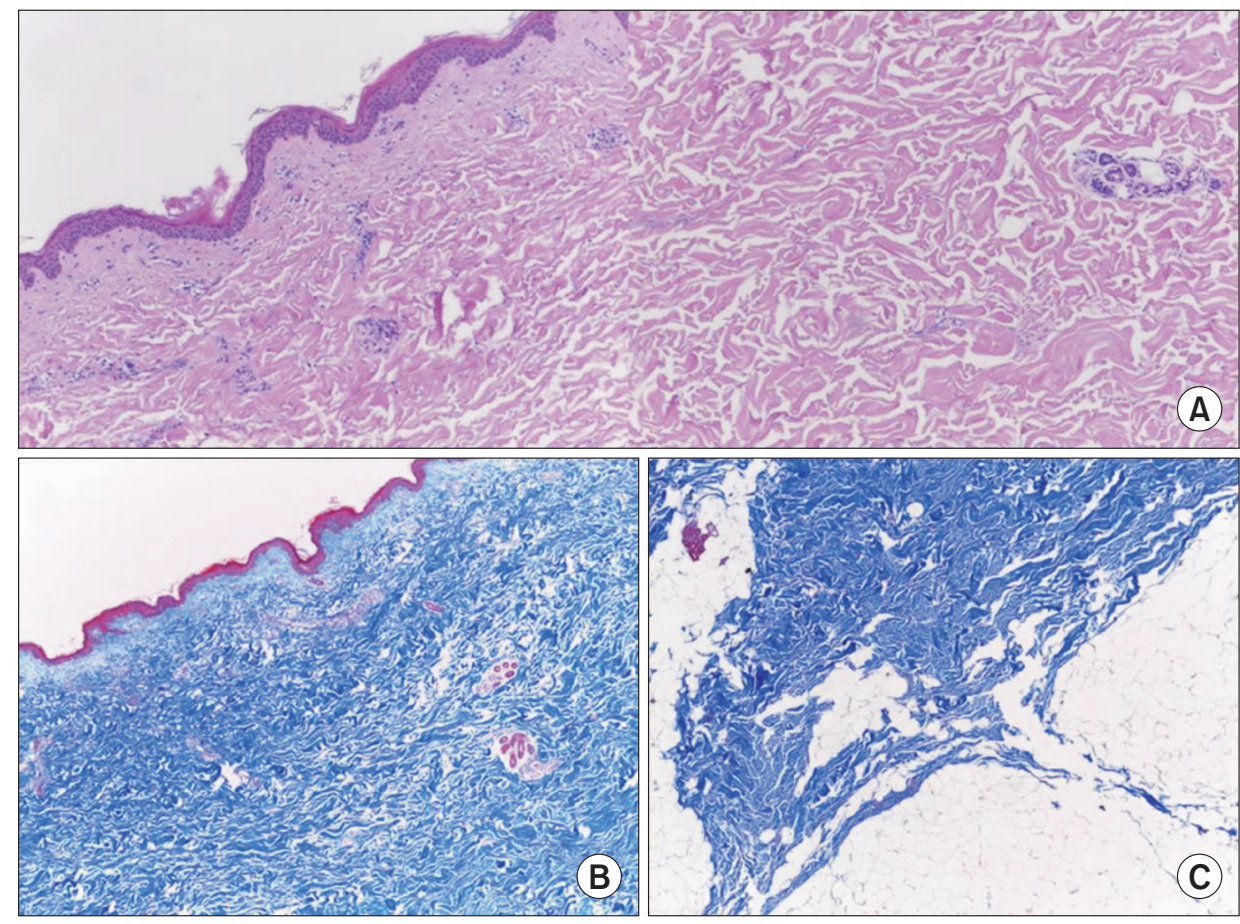

Fig. 3. Hematoxylin and eosin (A) and Masson's trichrome stain $(\times 100)(B, C)$ after freezingthawing. All tissue layers (epidermis, dermis, and subcutaneous fat) maintained structural integrity $(\times 40)$.

sutures in the superficial (Scarpa's) fascia, buried dermal suture, and accurate skin closure. A total of 53 first- and second-grade residents from general, plastic, orthopedic, cardiothoracic, dental surgery, and emergency medicine departments participated in the workshop, and 45 residents finished the questionnaire after the session; the results are summarized in Table 1. Average satisfaction scores regarding the tissue used in the education were more than 9.5 out of 10 (10: completely agree/ satisfied, 0: completely disagree/dissatisfied).
Table 2 summarizes total and specific item costs for the workshop program. Briefly, all 4 workshop sessions covering 53 residents cost 2,857,780 Korean Won (KRW), including 1,500,000 KRW for the instructor fees (52.5\%).

\section{DISCUSSION}

Duty-hour regulations for residents inevitably causes less time to be spent in the operating room for lower-grade residents 
$[1,2]$. In the United States, where the history of duty limitation is longer than that of the Republic of Korea, such concerns

Table 1. Summarized results of the questionnaire obtained from 10 residents

\begin{tabular}{lc}
\hline \multicolumn{1}{c}{ Question } & Answer \\
\hline $\begin{array}{l}\text { 1. Have you ever been involved in suture } \\
\text { technique training before? (Y/N) }\end{array}$ & Yes: $40 \%$ \\
2. Have you ever been trained / practiced with & Yes: $80 \%$ \\
artificial skin or pig skin? (Y/N) & \\
3. Was the session time length appropriate? & 8 \\
4. Do you believe the tissue you used was similar & 9.6 \\
to actual human tissue? & 9.6 \\
5. Was the tissue more helpful than the materials \\
previously used?
\end{tabular}

Forty-five first- and second-grade residents finished the questionnaire and the average satisfaction score regarding the tissue used in the education was 9.6 out of 10 (10: completely agree/ satisfied, 0: completely disagree/dissatisfied). generated a comprehensive strategy to maximize the operating experience for junior residents [3]. Nevertheless, technical developments such as laparoscopy and robotic procedures, along with recently-developed convenient devices such as absorbable staples and skin adhesives, also led to decreased opportunities for junior residents to participate in surgical procedures. Therefore, there is an increased need for efficient and effective surgical skills education.

With respect to suture technique education, placement of the suture at the accurate anatomic layer with proper tension is as important as proficiently handling surgical instruments, because secure knots with proper tension in the correct layer has a major impact on blood supply and the healing process of nearby tissue $[6,8]$. Various artificial suture pads or porcine skin are used for suturing education; however, these materials have different anatomic composition and cannot mimic human skin's soft elasticity [5,7]. A visual feedback system was developed to overcome the lack of accurate haptic feedback [8]. Nevertheless, elaboration regarding developing and verifying models for suture education remains relatively sparse compared to other aspects of surgical skills education [11,12].

Breast reconstruction is constantly increasing since its coverage by national health insurance in Korea, and the number of hospitals where autologous (especially abdominal tissue based) breast reconstruction is also increasing. The

Table 2. Total and specific item costs for four sessions of the workshop program covering 53 residents

\begin{tabular}{|c|c|c|c|c|}
\hline Category & Item & Unit cost (KRW) & Amount & Total cost (KRW) \\
\hline \multirow[t]{2}{*}{ Instructor fee } & Staff & 250,000 & 4 & $1,000,000$ \\
\hline & Fellow & 125,000 & 4 & 500,000 \\
\hline \multirow[t]{4}{*}{ Materials } & Wood board & 2,000 & 24 & 48,000 \\
\hline & Disposable bed pad (Depend) & 3,000 & 4 & 12,000 \\
\hline & Sterile gloves & 210 & 80 & 16,800 \\
\hline & Surgical blade & 92 & 40 & 7,360 \\
\hline \multirow[t]{8}{*}{ Sutures } & $\begin{array}{l}\text { ETHILON } 2 / 0 \\
\nabla / 45 \mathrm{~mm} / 100 \mathrm{~cm} / \text { nonabs }\end{array}$ & 1,178 & 60 & 70,680 \\
\hline & $\begin{array}{l}\text { ETHILON 3/0 } \\
\nabla / 26 \mathrm{~mm} / 45 \mathrm{~cm} / \text { nonabs }\end{array}$ & 1,356 & 60 & 81,360 \\
\hline & $\begin{array}{l}\text { ETHILON } 4 / 0 \\
\nabla / 19 \mathrm{~mm} / 45 \mathrm{~cm} / \text { nonabs }\end{array}$ & 1,356 & 60 & 81,360 \\
\hline & $\begin{array}{l}\text { ETHILON } 5 / 0 \\
\nabla / 16 \mathrm{~mm} / 45 \mathrm{~cm} / \text { nonabs }\end{array}$ & 1,673 & 60 & 100,380 \\
\hline & $\begin{array}{l}\text { PDS II 4/0 } \\
\nabla / 16 \mathrm{~mm} / 45 \mathrm{~cm} / \mathrm{abs}\end{array}$ & 3,327 & 60 & 199,620 \\
\hline & $\begin{array}{l}\text { PDS II 3/0 } \\
\nabla / 26 \mathrm{~mm} / 45 \mathrm{~cm} / \mathrm{abs}\end{array}$ & 3,327 & 60 & 199,620 \\
\hline & $\begin{array}{l}\text { VICRYL PLUS 2/0 } \\
\circ / 26 \mathrm{~mm} / 70 \mathrm{~cm} / \mathrm{abs}\end{array}$ & 4,505 & 60 & 270,300 \\
\hline & $\begin{array}{l}\text { VICRYL PLUS 1/0 } \\
\circ / 40 \mathrm{~mm} / 90 \mathrm{~cm} / \mathrm{abs}\end{array}$ & 4,505 & 60 & 270,300 \\
\hline Total & & & & $2,857,780$ \\
\hline
\end{tabular}

All 4 workshop sessions covering 53 residents cost 2,857,780 Korean Won (KRW), including 1,500,000 KRW for instructor fee (52.5\%). 
merits of using real frozen-thawed human full-thickness skin-subcutaneous tissue for suture education wound be substantial. This kind of tissue preservation for later use has already been widely-described and clinically-utilized in various medical fields [13]. The purpose of this article was to introduce a possible alternative in surgical skills education, for a large number simultaneously, presumably after finishing basic technique education and practice using existing models. Curriculum development and objective validation of its educational benefit is beyond the scope of this study. We could not find any previous study describing this type of frozenthawed normal tissue utilization from live humans for purely educational purpose. Nevertheless, we believe the value of proper education and training for medical students as well as for surgical residents would be as important as any study in terms of continuity and development of medicine.

In conclusion, frozen-thawed abdominal tissue remnants could be used for suture education for several residents at the same time. This could be more efficient than direct hands-on training in the operating room and would provide excellent anatomic structure and consistency at minimal cost. While this tissue can only be obtained in large centers performing abdominoplasty and/or autologous breast reconstruction, and sufficient ethical discussion should precede collection, we propose that cryopreserved human tissue remnants might be utilized in medical education and training upon complete anonymization and strict regulation.

\section{CONFLICTS OF INTEREST}

No potential conflict of interest relevant to this article was reported.

\section{ACKNOWLEDGEMENTS}

We sincerely thank professors Young-Mo Koo, University of Ulsan Colleage of Medicine, and Seung-Jun Hwang, University of Ulsan Colleage of Medicine, for their professional advice on this issue.

\section{REFERENCES}

1. Lee DY, Myers EA, Rehmani SS, Wexelman BA, Ross RE, Belsley SS, et al. Surgical residents' perception of the 16 . hour work day restriction: concern for negative impact on resident education and patient care. J Am Coll Surg 2012;215:868 77.

2. Scally CP, Reames BN, Teman NR, Fritze DM, Minter RM, Gauger PG. Preserving operative volume in the setting of the 2011 ACGME duty hour regulations. J Surg Educ 2014;71:580-6.

3. Healy JM, Maxfield MW, Solomon DG, Longo WE, Yoo PS. Beyond 250: a comprehensive strategy to maximize the operative experience for junior residents. J Surg Educ 2018;75:541-5.

4. Scott DJ, Goova MT, Tesfay ST. A costeffective proficiency-based knot-tying and suturing curriculum for residency programs. J Surg Res 2007;141:7-15

5. Khan S, Cipriano C, Marks JM, Schomisch

SJ. Porcine abdominal wall simulator for laparotomy incision and closure. Surg Innov 2015;22:426-31.

6. Miller CJ, Antunes MB, Sobanko JF. Surgical technique for optimal outcomes: part II. Repairing tissue: suturing. J Am Acad Dermatol 2015;72:389-402.

7. Hope WW, Watson LI, Menon R, Kotwall CA, Clancy TV. Abdominal wall closure: resident education and human error. Hernia 2010;14:463-6.

8. Horeman T, Blikkendaal MD, Feng D, van Dijke A, Jansen F, Dankelman J, et al. Visual force feedback improves knot-tying security. J Surg Educ 2014;71:133-41.

9. Bozola AR. Abdominoplasty: same classification and a new treatment concept 20 years later. Aesthetic Plast Surg
2010;34:181-92.

10. Newman MI, Samson MC. The application of laser-assisted indocyanine green fluorescent dye angiography in microsurgical breast reconstruction. J Reconstr Microsurg 2009;25:21-6.

11. Kim EY, Hong TH. In vivo porcine training model of laparoscopic common bile duct repair with $\mathrm{T}$-tube insertion under the situation of iatrogenic common bile duct injury. Ann Surg Treat Res 2018;94:142-6.

12. Lee JS, Hong TH. The rat choledochojejunostomy model for microsurgical training. Ann Surg Treat Res 2016;90:2469.

13. Mashiko T, Wu SH, Kanayama K, Asahi R, Shirado T, Mori M, et al. Biological properties and therapeutic value of cryopreserved fat tissue. Plast Reconstr Surg 2018;141:104-15. 